\title{
Usage of Facebook by University Students in Romania and Lithuania: A Comparative Study
}

\author{
Dragoş Daniel IORDACHE ${ }^{1}$, Costin PRIBEANU1, Vincentas LAMANAUSKAS ${ }^{2}$, Loreta \\ RAGULIENE ${ }^{2}$ \\ ${ }^{1}$ National Institute for Research and Development in Informatics - ICI Bucharest \\ ${ }^{2}$ Siauliai University \\ iordache@ici.ro,pribeanu@ici.ro,v.lamanauskas@ef.su.lt, loretar@gmail.com
}

Facebook is a social networking website which gained a huge popularity in the last decade among university students. Recent papers show that Facebook favors meeting new people, staying in touch with friends, getting useful information and knowledge, sharing of documents, joining groups and participating in group discussions. Although the usage of social networking websites in general and Facebook in particular has been extensively studied, this is little data available regarding the variations across countries, towns, and gender. This paper aims to comparatively analyze the results of two studies carried on in Lithuania and Romania. The data show that the reasons why university students are using Facebook differ from country to country and from town to town. Female university students have larger Facebook networks and spend more time on Facebook than male university students.

Keywords: Facebook, Social Networking Websites, University Students, Comparative Study.

\section{1} Introduction

Platforms supporting social networking on the Internet are applications for the creation, sharing and exchange of user-generated content that manifests in various forms: forums, blogs, instant messaging, collaborative projects, and virtual communities. Facebook (FB) is a social networking website that has an explosive growth in the last years and an increased popularity among university students $[2,17]$.

The shift of paradigm towards social learning brings in front various activities such as meeting, active participation, critical thinking, information and content sharing, collaboration, and debate. Last but not least, Facebook is favoring the offline university education of students $[4,5,14,16,13]$.

The usage of social networking websites in general $[18,3,10]$ and Facebook, in particular $[17,16]$ has been extensively studied. However, there is still little data available regarding the variations across countries, towns, faculty profile, and gender. Understanding how university students are using Facebook is important in order to exploit the potential benefits of social networking for the university life.
In order to explore the use of Facebook by university people, Lamanauskas et al. [11] carried on a qualitative study based on two focus groups in Siauliai University, Lithuania. Their findings show that Facebook is useful for individual and educational institution image and the formation of groups. In this moment, the educational possibilities are still not sufficiently used / revealed, so more investigations are needed in this area.

Iordache [8] carried on a similar study in Romania based on structured interview. His findings show that Facebook is easy to use and enables students to express themselves freely. According to students' perceptions, Facebook is useful for keeping in touch with people from home, facilitating of interactive activities, sharing of teaching and grouprelated materials, and formation of new groups.

Based on the results of previous work and these two qualitative studies a new evaluation instrument was developed in order to better understand why and how university students are using Facebook and which are the educational benefits of this social networking website [15].

This paper aims at comparatively presenting the results of two studies carried on in Lithu- 
ania and Romania based on the same evaluation instrument that was administrated in December 2014, respectively January 2015.

The main research questions of this study are:

- Why are university students using Facebook and how much is the usage related to the university context?

- How large is the network size of university students and how many Facebook friends are students?

- How often are university students logging on Facebook and how much time do they spend?

- How does usage vary across countries, towns, and gender?

\section{Method and Empirical Studies}

\subsection{Method and Data Sample}

The questionnaire was administrated to university students from three towns: Siauliai, Vilnius, and Bucharest. Respondents were asked to fill in several control variables (age, gender, university, faculty, year of study), usage variables (size of Facebook network, frequency of use, minutes per day), and then to evaluate several items on a 7 points Likert scale.

A total of 152 students from Lithuania (110 female, 42 male) and 62 students from Romania (110 female, 42 male) answered the questionnaire. Most of them are under graduate (144 from Lithuania and 62 from Romania). Lithuanian students' age is varying from 18 to $45(\mathrm{M}=23.47, \mathrm{SD}=5.62)$, most of the students $(79 \%)$ being between 18 and 25 years old.

Students are from four faculties in Lithuania and one faculty in Romania: technology and science (80), educology (57), arts (11), humanitarian (4), and electronics (62).

\subsection{Data Analysis}

SPPS 15 for Windows was used for statistical data analysis. In order to compare data, the two samples were merged in a working sample of 214 observations. The statistical significance of differences was analyzed with one-way ANOVA and t-test for equality of means that includes Levene's test for equality of variances.

\subsection{Variables and Descriptive Statistics}

This study is focusing on two sets of variables.

The first set of variables is related to the reasons to use Facebook and consists in 7 indicators measured on a 1-7 Likert scale. The indicators are presented in Table 1.

Table 1. Why do students use Facebook?

\begin{tabular}{|l|l|}
\hline Item & Statement \\
\hline $\begin{array}{l}\text { FBU } \\
1\end{array}$ & I use Facebook to present myself \\
\hline $\begin{array}{l}\text { FBU } \\
2\end{array}$ & $\begin{array}{l}\text { I use Facebook to find out what } \\
\text { happens in my university }\end{array}$ \\
\hline $\begin{array}{l}\text { FBU } \\
3\end{array}$ & $\begin{array}{l}\text { I use Facebook to get in touch with } \\
\text { new people }\end{array}$ \\
\hline $\begin{array}{l}\text { FBU } \\
4\end{array}$ & $\begin{array}{l}\text { I use Facebook to get advice about } \\
\text { something I am interested into }\end{array}$ \\
\hline $\begin{array}{l}\text { FBU } \\
5\end{array}$ & $\begin{array}{l}\text { I use Facebook to get access at } \\
\text { shared resources }\end{array}$ \\
\hline $\begin{array}{l}\text { FBU } \\
6\end{array}$ & $\begin{array}{l}\text { I use Facebook to participate in } \\
\text { group discussions }\end{array}$ \\
\hline $\begin{array}{l}\text { FBU } \\
7\end{array}$ & $\begin{array}{l}\text { I use Facebook to keep in touch } \\
\text { with former high school colleagues }\end{array}$ \\
\hline
\end{tabular}

The second set of variables is related to the actual use and consists in: size of a student's network (number of FB friends and number of FB student friends), frequency of use (days per week), time spent on FB (minutes per day), and frequency of requests asked from / sent by FB friends.

After analyzing frequencies and normality of the data, seven outliers in the number of FB friends were capped at 1500 , three outliers in the number of FB student friends were capped at 1000, and three outliers in time spent on FB were capped at 300 minutes.

The frequency of requests are measured on a 1-5 Likert scale (1=Never, 2=Rarely, $3=$ Sometimes, $4=$ Often, $5=$ Very often).

\section{Results}

3.1 Why do Students Use Facebook?

There are several differences between the 
two countries $(\mathrm{C})$ and the three towns $(\mathrm{T})$, as it could be observed in Table 2 .

Table 2. Differences between countries and towns

\begin{tabular}{|c|c|c|c|c|c|}
\hline Item & $\mathrm{C}$ & $\mathrm{T}$ & $\mathrm{N}$ & Mean & SD \\
\hline \multirow{3}{*}{ FBU1 } & \multirow{2}{*}{ LT } & $\mathrm{S}$ & 103 & 3.04 & 1.79 \\
\hline & & V & 49 & 3.29 & 1.34 \\
\hline & RO & B & 62 & 2.97 & 1.46 \\
\hline \multirow{3}{*}{ FBU2 } & \multirow{2}{*}{$\mathrm{LT}$} & $\mathrm{S}$ & 103 & 3.97 & 1.84 \\
\hline & & $\mathrm{V}$ & 49 & 4.88 & 1.54 \\
\hline & RO & B & 62 & 5.55 & 1.34 \\
\hline \multirow{3}{*}{ FBU3 } & \multirow{2}{*}{$\mathrm{LT}$} & $\mathrm{S}$ & 103 & 4.51 & 1.88 \\
\hline & & $\mathrm{V}$ & 49 & 4.84 & 1.72 \\
\hline & $\mathrm{RO}$ & $\mathrm{B}$ & 62 & 4.03 & 1.85 \\
\hline \multirow{3}{*}{ FBU4 } & \multirow{2}{*}{$\mathrm{LT}$} & $\mathrm{S}$ & 103 & 4.39 & 1.66 \\
\hline & & $\mathrm{V}$ & 49 & 4.86 & 1.47 \\
\hline & $\mathrm{RO}$ & $B$ & 62 & 4.68 & 1.62 \\
\hline \multirow{3}{*}{ FBU5 } & \multirow{2}{*}{ LT } & $\mathrm{S}$ & 103 & 4.31 & 1.79 \\
\hline & & V & 49 & 5.04 & 1.44 \\
\hline & $\mathrm{RO}$ & $\mathrm{B}$ & 62 & 5.63 & 1.38 \\
\hline \multirow{3}{*}{ FBU6 } & \multirow{2}{*}{ LT } & $\mathrm{S}$ & 103 & 4.69 & 1.86 \\
\hline & & V & 49 & 5.59 & 1.22 \\
\hline & RO & $\mathrm{B}$ & 62 & 5.18 & 1.62 \\
\hline \multirow{3}{*}{ FBU7 } & \multirow{2}{*}{$\mathrm{LT}$} & $\mathrm{S}$ & 103 & 5.50 & 1.42 \\
\hline & & V & 49 & 6.18 & 0.73 \\
\hline & RO & B & 62 & 5.00 & 1.89 \\
\hline
\end{tabular}

If we compare the data for the two countries, the mean values for Lithuanian university students are higher for FBU1 (selfpresenting), FBU3 (getting in touch with new people), FBU4 (getting advice about something), and FBU7 (keeping in touch with former high school colleagues). The mean values for Romanian university students are higher for the items FBU2 (finding out what happens in university), FBU5 (getting access at shared resources), and FBU6 (participating in group discussions).

It seems that Lithuanian students are more interested in using Facebook as a mean for communication and self-advertising while Romanian students are more interested in using Facebook for information and resources exchange. A t-test shows that the differences between the two countries are statistically significant for FBU2 $(\mathrm{p}<0.001), \quad$ FBU3 $(p=0.037)$, FBU5 $(p<0.001)$, and FBU7 $(\mathrm{p}=0.002)$.

Analysis of results for each town shows that the main reasons for the students in Bucharest are: FBU5 $(\mathrm{M}=5.63), \mathrm{FBU} 2(\mathrm{M}=5.55)$, and FBU6 $(\mathrm{M}=5.18)$. The main reasons for students in Vilnius are FBU7 $(\mathrm{M}=6.18)$, FBU6 ( $\mathrm{M}=5.59)$, and FBU5 $(\mathrm{M}=5.04)$, respectively FBU7 $(\mathrm{M}=5.50)$, FBU6 $(\mathrm{M}=4.69)$, and FBU3 $(\mathrm{M}=4.51)$ for the students in Siauliai.

A one-way ANOVA shows that differences between towns are statistically significant for the following items: FBU2 (F (2, $211)=18.53, \quad \mathrm{p}<0.001) \quad$ FBU5 $\quad(\mathrm{F}(2$, 211) $=13.44, \quad \mathrm{p}<0.001), \quad$ FBU6 $\quad(\mathrm{F}(2$, $211)=5.20, \quad \mathrm{p}=0.006), \quad$ and $\mathrm{FBU} 7 \quad(\mathrm{~F}(2$, 211) $=9.02, \mathrm{p}<0.001)$.

A gender analysis on the whole sample reveals that female students scored higher all items (see Table 3).

Table 3. Gender differences ( $\mathrm{N}=214)$

\begin{tabular}{|l|c|r|r|c|}
\hline Item & Gender & $\mathrm{N}$ & Mean & SD \\
\hline \multirow{2}{*}{ FBU1 } & male & 66 & 2.73 & 1.68 \\
\cline { 2 - 5 } & female & 148 & 3.23 & 1.55 \\
\hline \multirow{2}{*}{ FBU2 } & male & 66 & 4.20 & 1.83 \\
\cline { 2 - 5 } & female & 148 & 4.83 & 1.72 \\
\hline \multirow{2}{*}{ FBU3 } & male & 66 & 4.26 & 1.87 \\
\cline { 2 - 5 } & female & 148 & 4.53 & 1.84 \\
\hline \multirow{2}{*}{ FBU4 } & male & 66 & 4.41 & 1.54 \\
\cline { 2 - 5 } & female & 148 & 4.66 & 1.64 \\
\hline \multirow{2}{*}{ FBU5 } & male & 66 & 4.55 & 1.87 \\
\cline { 2 - 5 } & female & 148 & 5.00 & 1.60 \\
\hline \multirow{2}{*}{ FBU6 } & male & 66 & 4.79 & 1.85 \\
\cline { 2 - 5 } & female & 148 & 5.15 & 1.61 \\
\hline \multirow{2}{*}{ FBU7 } & male & 66 & 5.12 & 1.78 \\
\cline { 2 - 5 } & female & 148 & 5.68 & 1.35 \\
\hline
\end{tabular}

A t-test shows that the gender differences are statistically significant for FBU1 $(\mathrm{p}=0.041)$, FBU2 ( $p=0.018)$, and FBU7 $(p=0.012)$, and marginally significant for FBU5 $(p=0.070)$.

\subsection{How Large is the Network Size?}

The frequency chart for the network size of students in Lithuania is presented in Figure 1. 
Almost half of students (48\%) have between 100 and 300 hundreds of FB friends.

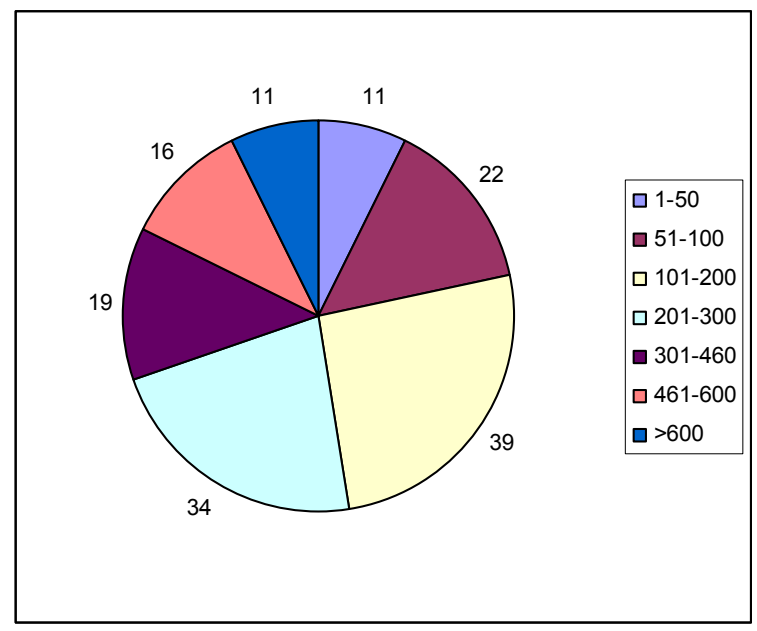

Fig. 1. Distribution of FB friends of Lithuanian university students $(\mathrm{N}=152)$

The frequency chart for the number of FB friends of university students in Romania is presented in Figure 2.

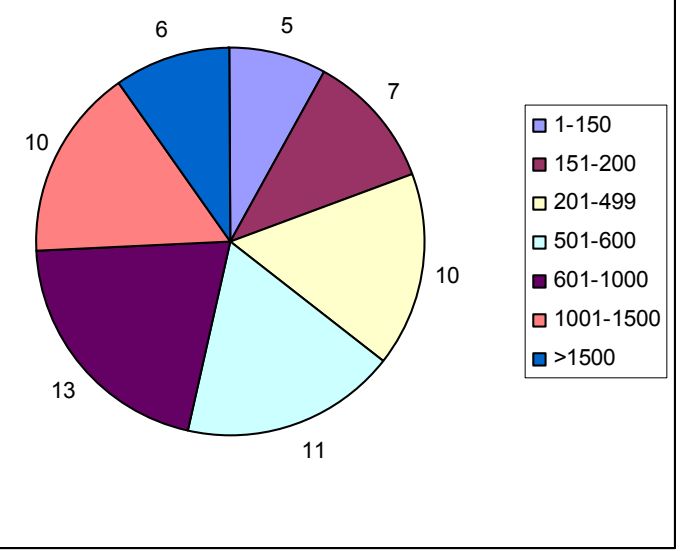

Fig. 2. Distribution of FB friends of Romanian university students $(\mathrm{N}=62)$

The distribution shows that the network size of Romanian students is pretty large: 22 students have up to $500 \mathrm{FB}$ friends, 24 students have between 500 and $1000 \mathrm{FB}$ friends and 16 students have more than 1000 FB friends. Overall, the network of Romanian students is much higher $(\mathrm{M}=659.61$ vs. $\mathrm{M}=280.38$ for FB friends, respectively $\mathrm{M}=400.68$ vs. $\mathrm{M}=48.93$ for $\mathrm{FB}$ student friends).

Regarding the network size and the number of student Facebook Friends, the data in Ta- ble 4 highlights several differences between the two countries.

The network size is higher for the students in Bucharest than for the students in Vilnius and for the students in Vilnius than for the students in Siauliai. A one-way ANOVA shows that differences are statistically significant for both the number of FB friends $(F(2$, $211)=50.102, \quad p<0.001)$ and the number of FB student friends $(\mathrm{F}(2,211)=104.982$, $\mathrm{p}<0.001)$ ).

Table 4. Facebook network size

\begin{tabular}{|c|c|c|c|c|c|}
\hline Variable & $\mathrm{C}$ & $\mathrm{T}$ & $\mathrm{N}$ & Mean & SD \\
\hline \multirow{3}{*}{$\begin{array}{l}\text { Face- } \\
\text { book } \\
\text { friends }\end{array}$} & \multirow{2}{*}{ LT } & V & 49 & $\begin{array}{r}394.2 \\
7\end{array}$ & 18 \\
\hline & & $\mathrm{S}$ & $\begin{array}{r}10 \\
3 \\
\end{array}$ & $\begin{array}{r}226.2 \\
0 \\
\end{array}$ & 66.40 \\
\hline & $\begin{array}{l}\mathrm{R} \\
\mathrm{O}\end{array}$ & B & 62 & $\begin{array}{r}695.6 \\
1 \\
\end{array}$ & 469.28 \\
\hline \multirow{3}{*}{$\begin{array}{l}\text { Face- } \\
\text { book } \\
\text { student } \\
\text { friends }\end{array}$} & \multirow[b]{2}{*}{ LT } & V & 49 & 70.63 & 87.09 \\
\hline & & $\mathrm{S}$ & $\begin{array}{r}10 \\
3 \\
\end{array}$ & 38.61 & 49.41 \\
\hline & $\begin{array}{l}\mathrm{R} \\
\mathrm{O}\end{array}$ & B & 62 & $\begin{array}{r}400.6 \\
8 \\
\end{array}$ & 352.68 \\
\hline
\end{tabular}

This is suggesting that the bigger the town the larger the Facebook network is. The town population for the three towns (thousands inhabitants) is as follows: 1883.4 for Bucharest, 539.9 for Vilnius, and 133.9 for Siauliai. In order to explore if the town size is predicting the Facebook network size, two simple linear regressions were performed between FB friends and FB student friends as dependent variables and the town population as independent variable. The Durbin-Watson test value was 1.878 , respectively 1.739 so we can conclude that the residuals are uncorrelated.

Table 5 displays the standardized regression coefficients $\beta$ and their significance, $R, R^{2}$, and adjusted $R^{2}$. In both cases the town population is significant at $\mathrm{p}<0.001$ level. The regression model explains $31.4 \%$ variance in the number of FB friends and $48.7 \%$ variance in the number of student FB friends.

The weight of FB student friends in the total network size is also different: $17.91 \%$ in Vil- 
nius, $17.07 \%$ in Siauliai, and $57.60 \%$ in $\mathrm{Bu}-$ charest.

It has been obtained, that Romanian respondents, having a very big friend group on FB account (on average 695.61), have a relatively big friend student group as well (on average 400.68). While Lithuanian respondents, having a smaller friend group on FB account (on average 310.24 ), have also a significantly smaller friend student group (on average 54.66). Lithuanian students from Siauliai have relatively the smallest student friend group on FB account. One can think, that this is because Siauliai university is not in a big town, is not big itself, and student groups are not big (on average 10-15 students), and students mostly communicate in their group and course. However, Vilnius respondents, being from a bigger town and a bigger university, have relatively bigger friend student group on FB account. This has a more significant expression among Romanian from Bucharest respondents.

Table 5. Regression analysis for the network

\begin{tabular}{|l|r|r|r|}
\hline \multicolumn{1}{|c|}{ Variables } & Beta & $\mathrm{t}$ & \multicolumn{1}{c|}{ Sig. } \\
\hline Dependent variable: FB friends \\
\hline $\begin{array}{l}\text { Town popula- } \\
\text { tion }\end{array}$ & .563 & 9.922 & .000 \\
\hline $\begin{array}{l}R=.563, R^{2}=.317, \text { Adj. } R^{2}=.314 ; \\
F(1,212)=98.442, \text { Sig. }=.000\end{array}$ \\
\hline Dependent variable: FB student friends \\
\hline $\begin{array}{l}\text { Town popula- } \\
\text { tion }\end{array}$ & .699 & 14.244 & .000 \\
\hline $\begin{array}{l}R=.699, R^{2}=.489, \text { Adj. } R^{2}=.487 ; \\
F(1,212)=202.890, \text { Sig. }=.000\end{array}$ \\
\hline
\end{tabular}

An analysis of gender differences on the whole sample shows that female students have larger FB networks $(\mathrm{M}=471.92$ vs. $\mathrm{M}=308.33$ ) with a higher number of university students $(M=182.56$ vs. $M=146.12)$. A ttest showed that the differences are not statistically significant.

\subsection{How often and how much time is spent on Facebook?}

The frequency chart for the time spent on Facebook by university students in Lithuania is presented in Figure 3. Most of the students (59.9\%) spend between 30 minutes and two hours on Facebook.

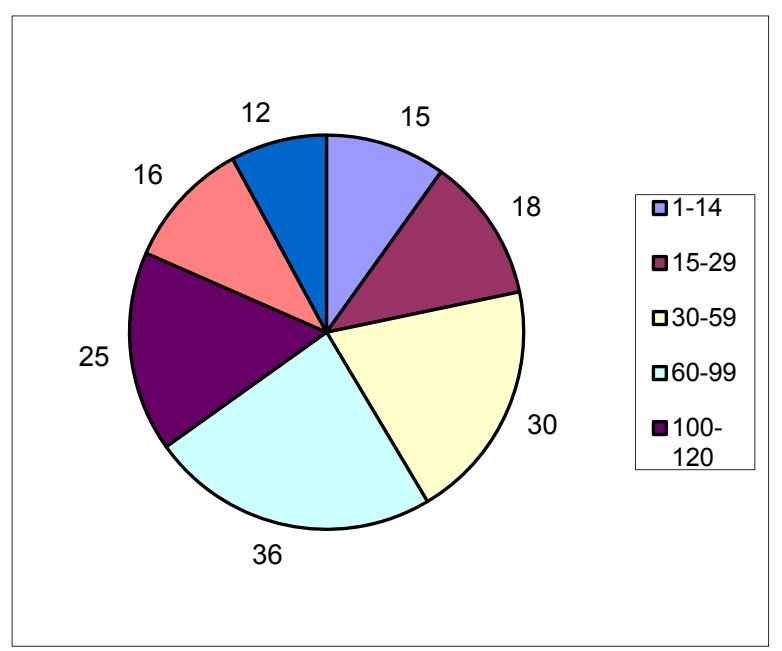

Fig. 3. Distribution of minutes spent per day on Facebook by Lithuanian university students $(\mathrm{N}=152)$

The frequency chart for the time spent on Facebook by university students in Romania is presented in Figure 4. Most of them (66.1\%) spend between 30 minutes and three hours on Facebook.

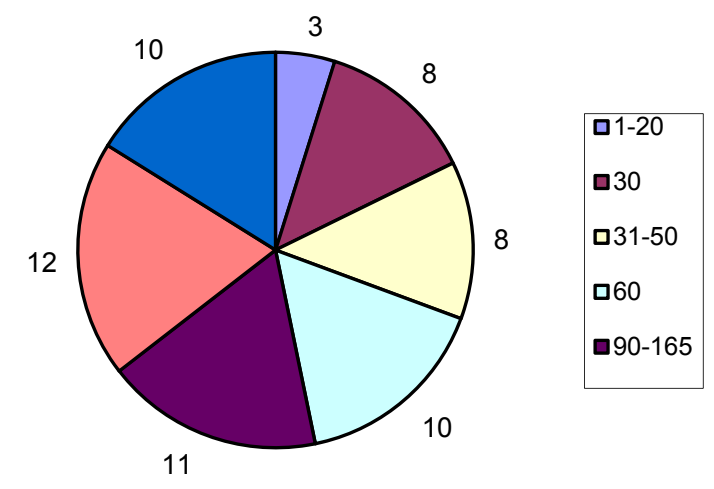

Fig. 4. Distribution of minutes spent per day on Facebook by Romanian university students $(\mathrm{N}=62)$

The data in Table 6 presents the mean values for the frequency of use and time spent on Facebook by university students from Siauliai, Vilnius, and Bucharest.

Overall, Romanian students spend much more time on Facebook that Lithuanian stu- 
dents $(M=130.77$ vs. $M=83.18)$. A t-test shows that the difference is significant $(p=0.001)$. The difference for the frequency of use is smaller $(\mathrm{M}=6.54$ vs. $\mathrm{M}=6.22)$ and statistically not significant.

Table 6. Frequency of use and time spent on FB

\begin{tabular}{|l|l|c|r|r|r|}
\hline Variable & $\mathrm{C}$ & $\mathrm{T}$ & $\mathrm{N}$ & \multicolumn{1}{c|}{$\mathrm{M}$} & \multicolumn{1}{c|}{ SD } \\
\hline \multirow{2}{*}{$\begin{array}{l}\text { Days } \\
\text { per }\end{array}$} & \multirow{2}{*}{$\begin{array}{l}\text { WT } \\
\text { Week }\end{array}$} & $\mathrm{S}$ & 103 & 5.92 & 1.77 \\
\cline { 2 - 6 } & $\mathrm{RO}$ & $\mathrm{B}$ & 49 & 6.84 & 0.55 \\
\hline \multirow{2}{*}{$\begin{array}{l}\text { Minutes } \\
\text { per Day }\end{array}$} & \multirow{2}{*}{$\mathrm{LT}$} & $\mathrm{S}$ & 103 & 74.20 & 81.58 \\
\cline { 2 - 6 } & $\mathrm{V}$ & 49 & 102.06 & 66.89 \\
\cline { 2 - 6 } & $\mathrm{RO}$ & $\mathrm{B}$ & 62 & 130.77 & 113.69 \\
\hline
\end{tabular}

There are differences across towns regarding the time spent on Facebook. A one-way ANOVA shows that the differences are significant $(\mathrm{F}(2,211)=7.23, \mathrm{p}=0.001))$

A regression analysis was performed for the time spent on Facebook having as predictor the town population. Table 7 displays the standardized regression coefficients $\beta$ and their significance, $\mathrm{R}, \mathrm{R}^{2}$, and adjusted $\mathrm{R}^{2}$. The regression model explains $20.3 \%$ variance in the number of FB friends and $36.6 \%$ variance in the number of student $\mathrm{FB}$ friends.

Table 7. Regression analysis for the network

\begin{tabular}{|l|r|r|r|}
\hline \multicolumn{1}{|c|}{ Variables } & Beta & $\mathrm{t}$ & \multicolumn{1}{c|}{ Sig. } \\
\hline Dependent variable: Minutes per day \\
\hline $\begin{array}{l}\text { Town popula- } \\
\text { tion }\end{array}$ & .240 & 3.600 & .000 \\
\hline \begin{tabular}{l}
$R=.240, R^{2}=.058$, Adj. $R^{2}=.0 .053$, \\
$F(1,212)=12.692$, Sig. $=.001$ \\
\hline
\end{tabular}
\end{tabular}

An analysis of gender differences on the whole sample shows that female students log on more frequently ( $\mathrm{M}=6.44$ vs. $\mathrm{M}=6.02$ days per week) and spend more time on Facebook ( $M=98.37$ vs. $M=93.83$ minutes per day) than male students. A t-test showed that the differences are statistically significant only for the frequency of use $(\mathrm{p}=0.043)$.

Other two variables of interest are the frequency of requests sent and received from Facebook friends. The data in Table 8 pre- sents the mean values for university students in Siauliai, Vilnius, and Bucharest.

In all cases the mean values are higher for university students in Romania and in bigger towns. A one-way ANOVA showed that differences between the perceptions of university students in different towns are statistically significant $(\mathrm{F}(2,211)=8.47, \mathrm{p}<0.001$ respectively $(\mathrm{F}(2,211)=12.27, \mathrm{p}<0.001))$.

Table 8. Frequency of requests sent and received

\begin{tabular}{|l|l|c|r|c|c|}
\hline Variable & $\mathrm{C}$ & $\mathrm{T}$ & \multicolumn{1}{c|}{$\mathrm{N}$} & $\mathrm{M}$ & $\mathrm{SD}$ \\
\hline Frequency & $\mathrm{LT}$ & $\mathrm{S}$ & 103 & 2.88 & 0.94 \\
\cline { 2 - 6 } $\begin{array}{l}\text { of asking } \\
\text { something }\end{array}$ & $\mathrm{V}$ & 49 & 3.31 & 0.98 \\
\cline { 2 - 6 } & $\mathrm{RO}$ & $\mathrm{B}$ & 62 & 3.50 & 1.02 \\
\hline $\begin{array}{l}\text { Frequency } \\
\text { of being } \\
\text { asked } \\
\text { something }\end{array}$ & $\mathrm{LT}$ & $\mathrm{S}$ & 103 & 3.09 & 0.91 \\
\cline { 2 - 6 } & $\mathrm{RO}$ & $\mathrm{B}$ & 49 & 3.63 & 0.78 \\
\hline
\end{tabular}

These results correlate well with the friend and student friend number on FB account. The more FB user has friends and student friends on his FB account, the more frequently they are asking something and are being asked something.

This suggests that the interaction between university students is more intense in bigger towns.

A gender analysis on the whole sample shows that male students ask a little bit more from their FB friends $(M=3.18$ vs. $M=3.15)$ while female students are asked a little bit more by their FB friends $(\mathrm{M}=3.41 \mathrm{vs}$. $\mathrm{M}=3.36$ ). A t-test showed that the differences are not statistically significant.

\section{Discussion}

The comparative analysis of Facebook usage in Romania and Lithuania suggests that several differences exist between countries and towns.

Romanian university students have larger Facebook networks and the weight of students in the total FB friends is larger. In both countries, female students have larger FB networks and spend more time on Facebook than male students. 
In 2013, a 7 country FB comparative analysis was carried out [10]. Romanian and Lithuanian students participated in the research. It has been obtained, that in the group of the respondents from Romania, FB has the strongest expression as a means of education and information, $(\mathrm{RO}, \mathrm{PI}=0.70)$. Romanian respondents also rather highly value FB leisure and communication function $(\mathrm{RO}, \mathrm{PI}=$ 0.65). Acknowledging that $\mathrm{SN}$ is really a good means of communication and spending leisure time, they still discern a bigger benefit in using SN in obtaining new knowledge, the newest information from the whole world without going out from home. For Lithuanian respondents both these FB functions are equally significant: both of communication and leisure and of education and information factors $(\mathrm{LT}, \mathrm{PI}=0.64)$. A similar tendency remains in this research as well. Lithuanian students are more interested in using Facebook as a means of communication and selfadvertising. Romanian students are more interested in using Facebook for information and resource exchange. On the whole, the researches show that $18 \%$ of public universities in Romania have Facebook and Twitter accounts [1]. At the same time, students' positions on Facebook usage question are also rather "circumspect". The other authors' researches also show that only $26.7 \%$ of the Romanian students perceive the use of Facebook as an important instrument of change in higher education [6]. In Lithuanian student population the situation is pretty different. Over the latter several years, increasing popularity of social media and Facebook has been observed in students' daily life [9].

\section{Conclusion}

In this study a comparative analysis of Facebook usage by Lithuanian and Romanian students was presented. The results reveal several variations that should be further investigated across countries and towns.

There are inherent limitations of this work since the study is exploratory. The sample used in this study is relatively small and gender unbalanced. Students came from only three universities and the number of Siauliai students is more than twice larger than the number of Vilnius students or the number of Bucharest students.

Regarding the relationship between the town population from one side and the network size and time spent on Facebook, on the other side, the regression results should be taken with caution. However, a strong relationship exists that should stimulate further research since it is likely that at least for the same country and for a given period of time, the town population could predict Facebook usage.

\section{Acknowledgement}

This work was supported in part from a Romanian national grant financed by the $\mathrm{Na}$ tional Agency for Scientific Research under TEHSIN 09230207.

\section{References}

[1] E. L. Alexa, M. Alexa, C. M. Stoica, (2012). The use of online marketing and social media in higher education institutions in Romania. Journal of Marketing Research \& Case Studies, 1-9. Doi: 10.5171/2012.721221.

[2] R. Arteaga Sánchez, V. Cortijo, \& U. Javed, (2014). Students' perceptions of Facebook for academic purposes. Computers \& Education, 70, 138-149.

[3] P.B. Brandtzaeg, (2012) Social networking sites: Their users and social implications -a longitudinal study. Journal of Computer-Mediated Communication, 17. 467-488.

[4] J. S. Brown, \& R. P. Adler, (2008). Open education, the long tail, and learning 2.0. Educause review, 43(1), 16-20.

[5] C. Greenhow, B. Robelia, (2009) Informal learning and identity formation in online social networks. Learning, Media and Technology, 34, 119-140.

[6] G. Grosseck, R. Bran, L. Tiru, (2011). Dear teacher, what should I write on my wall? A case study on academic uses of Facebook. Procedia - Social and Behavioral Sciences, 15, 1425-1430. doi:10.1016/j.sbspro.2011.03.306.

[7] D. D. Iordache, \& V. Lamanauskas, 
(2013). Exploring the Usage of Social Networking Websites: Perceptions and Opinions of Romanian University Students. Informatica Economica 17 (4), 1825.

[8] D. D. Iordache, (2014) Characteristics of Facebook use by students - a qualitative approach. Proc. RoCHI 2014 (Popovici D., M., Iordache D., D., Eds.) Conferinta Nationala de Interactiune OmCalculator, 91-94.

[9] V. Kumpikaite, K. Duoba, Taraskevicius, A. (2011). Will such Information Technology as Facebook Become Regular Mean for Study Process? In. 3rd International Conference on Advanced Management Science, IPEDR, Vol. 19 (pp. 36-40). Singapore: IACSIT Press. Retrieved from http://www.ipedr.com/vol19/7ICAMS2011-A00013.pdf .

[10] V. Lamanauskas, V. Slekiene, A. Ba$\log$, C. Pribeanu (2013). Exploring the usefulness of social networking websites: a multidimensional model. Studies in Informatics and Control, 22(2), 175-184.

[11] V. Lamanauskas, V. Šlekienè, L. Raguliene, (2014). Educational facebook usage context: university teachers and students' position. Gamtamokslinis $U g$ dymas/Natural Science Education, 1 (39), 7-13.

[12] V. Lamanauskas, V. Šlekienė, L., Raguliene, D. D. Iordache, C. Pribeanu, M. Bílek, B. Cavas, T. Mazurok, (2013). Social networking websites from the point of view of university students: a compar- ative analysis. Problems of Education in the 21st Century, 57, 61-78

[13] C. Lampe, Y.W. Donghee, J. Vitak, N.B. Ellison, (2011) Wash, R. Student use of Facebook for organizing collaborative classroom activities. ComputerSupported Collaborative Learning, 6:329-347.

[14] C. Madge, J. Meek, J. Wellens, \& T. Hooley, (2009). Facebook, social integration and informal learning at university: 'It is more for socialising and talking to friends about work than for actually doing work'. Learning, Media and Technology, 34(2), 141-155.

[15] C. Pribeanu, A. Balog, V. Lamanauskas, V. Šlekienè (2015) Social capital on Facebook as perceived by Lithuanian university students. Journal of Baltic Science Education 14(1), 132-141.

[16] N. Selwyn, (2009). Faceworking: exporing students' education-related use of Facebook. Learning, Media, and Technology 34(2), 157-174.

[17] C. Steinfield, N. B. Ellison, \& C. Lampe, (2008). Social capital, selfesteem, and use of online networks sites: A longitudinal analysis. Journal of Applied Developmental Psychology, 29, 434-445.

[18] S. Valenzuela, N. Park, \& K. F. Kee, (2009). Is There Social Capital in a Social Network Site?: Facebook Use and College Students' Life Satisfaction, Trust, and Participation. Journal of ComputerMediated Communication, 14(4), 875901.

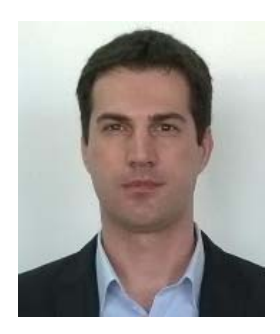

Dragoş Daniel IORDACHE received the $\mathrm{PhD}$ degree in Education Sciences from the University of Bucharest in 2011. Currently he is a scientific researcher at ICI Bucureşti. Dragoș Daniel Iordache is a member of the Romanian HCI group (RoCHI - SIGCHI Romania) and he served as conference reviewer for the last editions of the national conference. His research interests include: usability and pedagogical evaluation of educational systems, usability guidelines, user testing and heuristic evaluation. He is author / co-author of 3 book chapters, 10 journal papers and 20 conference papers. 


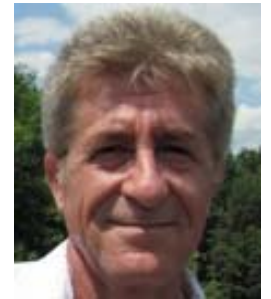

Costin PRIBEANU received the $\mathrm{PhD}$ degree in Economic Informatics from the Academy of Economic Studies in 1997. Currently he is a senior researcher I at ICI Bucureşti. Costin Pribeanu is Vice-Chair for conferences of the Romanian HCI group (RoCHI - SIGCHI Romania) since 2009. His research interests include: model-based engineering, task-based design, usability and accessibility evaluation, social networks. He is author / co-author 50 conference papers.

of 4 books, 6 edited books, 8 book chapters, over 70 journal papers and over

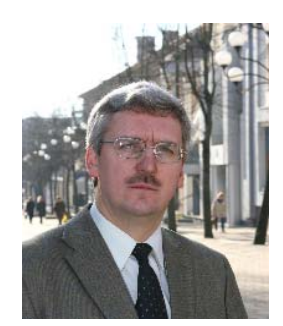

Vincentas LAMANAUSKAS is Professor in Education Sciences, Head of Natural Science Education Research Centre at Siauliai University, Lithuania. His research interests include: comparative educational issues, problems of natural science education in comprehensive school, psycho-physiological aspects of interaction between nature and human being, national and contemporary education management and politics, quality of management. He published more than 450 scientific and methodic articles and 20 methodicdidactic publications in Lithuanian and foreign press.

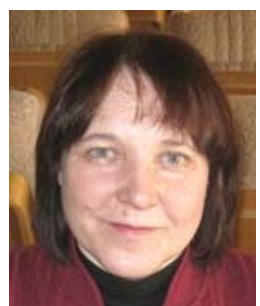

Loreta RAGULIENE - PhD. is associate professor, Faculty of Technology and Natural Sciences, Siauliai University, Lithuania. Her research interests include: physics teaching, ICT in science education, non-formal science education. She also is the head of Junior physicists' school "PHOTON" at the Siauliai University. 